\title{
Indoor Air Contaminant Adsorption By Palm Shell Activated Carbon Filter - A Proposed Study
}

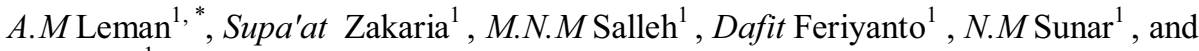 \\ N.Misdan ${ }^{1}$ \\ ${ }^{1}$ Faculty of Engineering Technology, Universiti Tun Hussein Onn Malaysia (UTHM), Parit Raja, \\ Batu Pahat, 86400 Johor, Malaysia.
}

\begin{abstract}
Indoor air contaminant is a public issue. High Volatile Organic Compound (VOC), Carbon monoxide (CO), Carbon dioxide $\left(\mathrm{CO}_{2}\right)$, and particulate matter is becoming main issue that needs to solve. Therefore, this study focus on improving indoor air quality by using activated carbon (AC) for Ventilation and Air-Conditioning (VAC). It investigated because $\mathrm{AC}$ is widely explored but developing $\mathrm{AC}$ as a filter for $\mathrm{VAC}$ is not developed yet. The AC prepared by physical and chemical activation process and combination both of process and it was activated by $\mathrm{H}_{3} \mathrm{PO}_{4}$ and $\mathrm{NaOH}$. Characterization and analysis process are consists of water content, ash content, bulk density, adsorption capacity, iodine number and indoor air filtering analysis. Treated activated carbon potential in achieving higher surface area of the structure to the range of 950 to $1150 \mathrm{~m}^{2} / \mathrm{g}$ for gas phase application. The higher surface area will adsorb more air pollution. Maintained properties of activated carbon such as hardness, density, pore, extractable ash, particle size (12 by 40 mesh) and $\mathrm{pH}$ are becoming the main concern in achieving high quality of activated carbon.
\end{abstract}

\section{Introduction}

Demanding of fresh, healthy and comfortable indoor environment is essential since most people spend their time in indoor as compared to outdoor [1]. The increasing concern towards indoor air quality (IAQ) have gained the suitable technique on mitigating the indoor air contaminant [2] which can effect on health and working performance [3]. Volatile Organic Compound (VOC), Carbon monoxide (CO), Carbon dioxide $\left(\mathrm{CO}_{2}\right)$, and particulate matter defined as the major contribution of indoor air contaminant. There are several VOCs in indoor air environment such as BTX (benzene, toluene xylene), trichloroethylene and dichloromethane [4]. During long term exposure may pose adverse health effect related to human respiratory systems (such as asthma, throat irritation, lung cancer), headache, poor memory, eyes, nose and also skin irritation $[5,6]$. In order to decrease the pollutant, some researchers have been conducting their methods for controlling

\footnotetext{
${ }^{*}$ Corresponding author: mutalib@uthm.edu.my
} 
the VOC such as adsorption, condensation, Photocatalytic oxidation (PCO), negative air ions (NAIs) and non-thermal plasma (NTP) [4]. In recent years, adsorption in bulk separation or purification process has an innovative treatment process in environment application. Adsorption method is effective at low concentration level which is Part per million (ppm). Larger adsorption capacity is achieved by larger surface area of the filter material and their performance in both equilibrium and kinetics.

Generally the concentration of indoor air contaminant is higher than outdoor because it's released by human activities, building materials, furniture, carpets, paints, cleaning product, etc. [7]. Therefore, the maintenance of the indoor air quality is quite needed in order to provide sustainable and healthy environment [8].

There were some approaches methods that has been used for controlling indoor air pollutant such as ventilation and air cleaning method [9]. Mechanical Ventilation and AirConditioning (MVAC) system have been improved by reducing indoor particulate level. However, this technique is not promising to diminish of contaminant gases and require more energy consumption [10]. Air purification through activated carbon adsorption technique being most common air cleaning method especially for VOC and other polluted gases [11]. There are several adsorption media which commercially available or existing in the market such as Activated Carbon Fiber (ACF), Silica gel, zeolite, alumina and Granular Activated Carbon (GAC). According to some literature that the constant temperature and relative humidity in a real building for various condition is may vary significantly between months, seasons and years $[12,13]$. However, the filter in the market has not been evaluated yet which led to a real VOC contaminant is real building is not recorded [13]. One of the technology which effective and reliable for removing impurities is by using activated carbon filter. Activated carbon is one of the cheapest and popular material as water purification, cleaned/desorption which used hundred or thousand times [14]. There are many advantages of activated carbon such as high carbon content, high density and low ash content, high absorption capacity, for dissolved organic, chlorine and can be used as specific application [14-17]. The other superiority of activated carbon is a reasonable large surface area, have numerous pore network (Figure 1) as a transportation media of the molecule to the interior and it's more stable performance in dynamic condition [18]. Influencing by high pollutant in our environment and many superiority of activated carbon, Therefore, the activated carbon is urgently needed in filtering the pollutant into fresh air. The principle of filtering process of activated carbon is to convert the pollutant to the $\mathrm{CO}_{2}$, $\mathrm{H} 2 \mathrm{O}$ as shown in Figure 2.

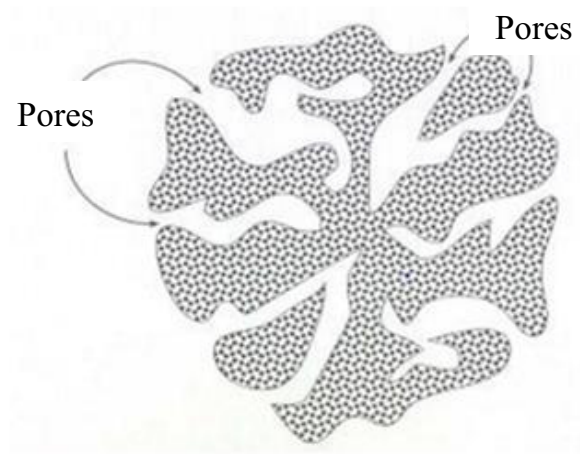

Fig. 1. Numerous pores of the activated carbon [18]. 


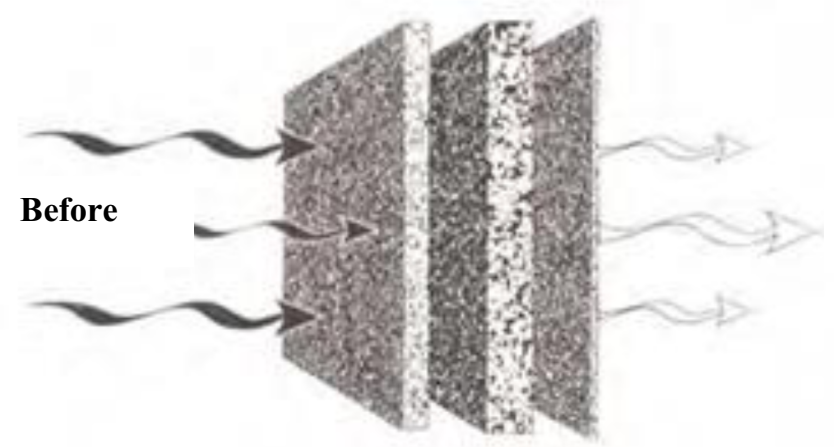

After

Fig. 2. Air before and after filtered by activated carbon $[8,13]$.

$\mathrm{AC}$ as an indoor air filter in order to improve indoor air quality and to reduce the cancer risk and non-cancer risk health problem. There are many researchers' studies on increasing the pore development of palm shell activated carbon $[8,13,14,19-22]$. The pore development on activated carbon can be increased by undergoing physical and chemical treatment. In Malaysia, the palm shell is abundant due to there are 4,853,766 hectares oil palm forest in 2010 [23]. Therefore, palm shell AC (Figure 3) is very potential to explore in Malaysia.

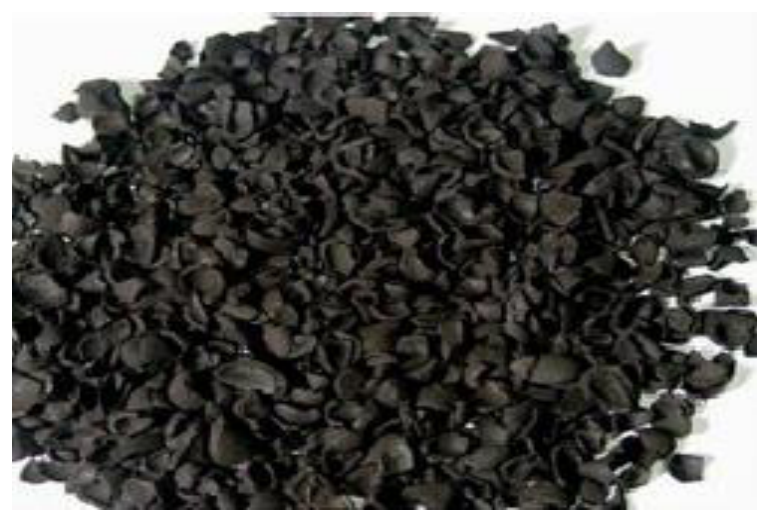

Fig. 3. Palm shell activated carbon [23].

According to Abdullah and Wahid [23], their AC has several base properties such as bulk density (0.4-0.47), moisture content (3\%), ball-pan hardness (90-95\%), ash content $(5-7 \%)$, iodine number $(950-1100 \mathrm{mg} / \mathrm{g})$ and $\mathrm{pH}$ value $(10)$.

\section{Surface Modification of Palm Shell Activated Carbon}

Surface modification is conducted using physical and chemical treatment. That treatment is conducted to achieve good pore structure and good adsorption properties.

\subsection{Physical Activation Process}

Physical activation of $\mathrm{AC}$ is consists of 2 steps which are hydrogen and oxygen content elimination by using pyrolysis carbonaceous material at inert atmosphere and at high temperature. Second steps are chars activation at high temperature and in the presence of 
$\mathrm{CO}_{2}$ as oxidizing gases [24]. According to Abechi et al. [18], that highest physicochemical properties are signed by the sample which treated at a temperature of $1000^{\circ} \mathrm{C}$, holding time of $45 \mathrm{~min}$, Yiel of $19.25 \%$ and bulk density of $0.62 \mathrm{gcm}^{-3}$ and its micostructure analysis as shown in Figure 4.

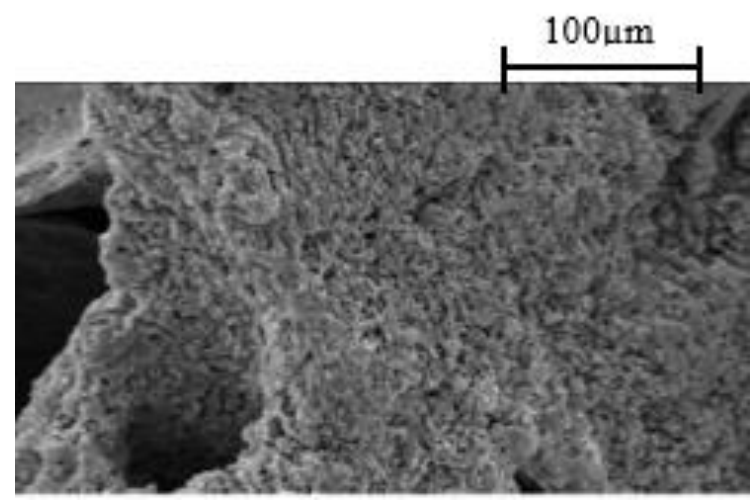

Fig. 4. Microstructure of treated $\mathrm{AC}$ in temperature and holding time of $1000^{\circ} \mathrm{C}$ and $45 \min [18]$.

Figure 4 shows a highest adsorption capacity with surface area of $217 \mathrm{gm}^{-2}$, micropore volume $(\mathrm{V} \mu)$ is $11 \times 10^{-2} \mathrm{~cm}^{-3} \mathrm{~g}^{-1}$ and mesopore volume of $1 \times 10^{-2} \mathrm{~cm}^{-3} \mathrm{~g}^{-1}$. During physical activation process, There are 2 major reactions as in Eq. 1 and Eq. 2 [18].

$$
\begin{gathered}
\mathrm{C}+\mathrm{CO}_{2} \rightarrow 2 \mathrm{CO} \\
\mathrm{C}+\mathrm{H}_{2} \mathrm{O} \rightarrow \mathrm{CO}+\mathrm{H}_{2}
\end{gathered}
$$

Physical treatment or thermal activation is conducted by carbonization of palm shell at the temperature range of 500 to $900{ }^{\circ} \mathrm{C}$ in order to remove volatile metter. Many researchers used different temperature in thermal activation such as $500^{\circ} \mathrm{C}[25,26], 600^{\circ} \mathrm{C}$ $[26,27], \quad 700^{\circ} \mathrm{C}[26,28], 800^{\circ} \mathrm{C}[18,26,29], 900^{\circ} \mathrm{C}[18,24], 1000^{\circ} \mathrm{C}[18]$ and $1200^{\circ} \mathrm{C}$ [24]. The influence of the temperature in enlargement of pores and to enhance the adsorption solvent by increasing activation temperature [30]. The normal physical activation time for palm shell activated carbon is 1-8 hours [31]. Moreover, physical activation process also varied by relative pressure $(\mathrm{P} / \mathrm{Po})$ in the range of 0 to 1 with the highest adsorption capacity is signed by A1 sample of $80 \mathrm{~cm} 3 / \mathrm{g}$ STP in 1 relative pressure like shown in Figure 5 [18].

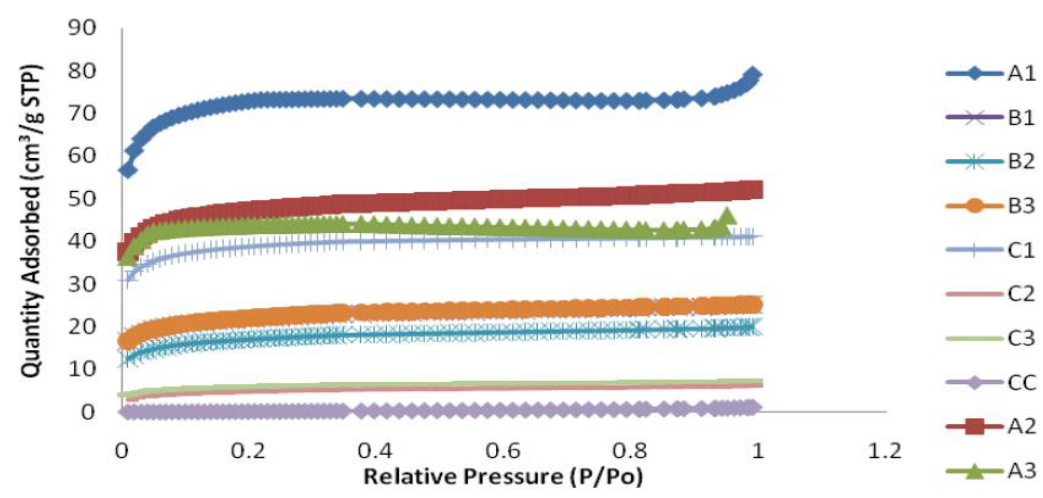

Fig. 5. Adsorption capacity of AC in different relative pressure [18]. 


\subsection{Chemical Activation Process}

The chemical activation process of AC covers the precursor treatment with chemical agent and followed by heat treatment which influence to the carbonization process and porosity generation $[26,32]$. There are some dehysrating agent such as phosporic acid $\left(\mathrm{H}_{3} \mathrm{PO}_{4}\right)$, zing chloride $(\mathrm{ZnCl} 2)$ and natrium hydroxide $(\mathrm{NaOH})$ [26]. The chemical analysis of palm shell is shown in Table 1.

Table 1. Chemical analysis of oil palm shell as activated carbon material [29]

\begin{tabular}{|l|l|l|l|l|l|}
\hline \multicolumn{2}{|c|}{$\begin{array}{c}\text { Approximate analysis } \\
(\mathbf{w t \% )}\end{array}$} & \multicolumn{2}{c|}{ Element analysis (wt\%) } & \multicolumn{2}{c|}{ Content (wt\%) } \\
\hline Fixed carbon & 18.7 & $\mathrm{C}$ & 50.01 & Cellulose & 29.7 \\
\hline Ash & 7.96 & $\mathrm{H}$ & 6.85 & Halo cellulose & 47.7 \\
\hline Moisture & 1.1 & $\mathrm{~N}$ & 1.9 & Lignin & 53.4 \\
\hline Volatile & 72.46 & $\mathrm{O}$ & 41.15 & & \\
\hline
\end{tabular}

There are many researchers which conduct the chemical activation process in producing activated carbon using various chemical agents as listed in Table 2.

Table 2. Chemical agent for activating charcoal

\begin{tabular}{|l|l|}
\hline \multicolumn{1}{|c|}{ Chemical agent } & \multicolumn{1}{c|}{ Composition } \\
\hline $\mathrm{H}_{3} \mathrm{PO}_{4}$ & $85 \%[24]$ \\
\hline $\mathrm{ZnCl}$ & \\
\hline $\mathrm{NaOH}$ & $65 \%[26] ; 98 \%[24]$ \\
\hline $\mathrm{KOH}$ & $1000 \mathrm{mg} / \mathrm{L}[33] ; 10$ to $300 \mathrm{mg} / \mathrm{L}[34]$ \\
\hline $\mathrm{HNO}_{3}$ & $50 \%[18]$ \\
\hline $\mathrm{K}_{2} \mathrm{CO}_{3}$ & $1000 \mathrm{mg} / \mathrm{L}[33]$ \\
\hline $\mathrm{H}_{2} \mathrm{SO}_{4}$ & $1000 \mathrm{mg} / \mathrm{L} \mathrm{[33]}$ \\
\hline $\mathrm{NaHCO}_{3}$ & 10 to $300 \mathrm{mg} / \mathrm{L}[34]$ \\
\hline $\mathrm{NaCl}$ & 10 to $300 \mathrm{mg} / \mathrm{L}[34]$ \\
\hline
\end{tabular}

\section{Research Approch}

AC is produced by some methods and it have explored by many researchers. The activation process is divided into 2 types which are physical (various temperature between 500 to $900^{\circ} \mathrm{C}$ [25] and time of 1-8 hours [31] and chemical activation as listed in Table 2. It has conducted using various temperature, and chemical agent. According to Niya et al., (2011) [24] $\mathrm{H}_{3} \mathrm{PO}_{4}$ is used as chemical agent which heat treatment under temperature of 900 and $1200^{\circ} \mathrm{C}$. Abechi et al. [18] also activate the palm shell using a chemical agent of $\mathrm{KOH}$ and treated under temperature of 800,900 and $1000^{\circ} \mathrm{C}$. Palm shell was burned in various temperature using commercially burner that unidentified reference of burner design [23, 33, 34]. The burner may not frequently release the heat flow and air flow which cause overheated of the burner and it led to a high volume of its content and decreasing adsorption properties of activated carbon. After burned, palm shell is cruised and sieved in various sizes such as 1-2 $\mathrm{mm}$ [24], $1.18 \mathrm{~mm}$ [18], 1.0-2.0 $\mathrm{mm}$ [35], 250-300 $\mu \mathrm{m}$ diameter [19] and $425 \mu \mathrm{m}$ [36]. There is some limitation of those researches in combining the activation process, and in burning process. That process is strictly controlled in order to achieve high quality activated carbon based on the adsorption capacity/ surface area, hardness, density, pore, extractable ash, particle size and $\mathrm{pH}$. 
Research Approach is more to innovative technology and treatment process. It involves the burning process which is a fabrication process based on air and heat flow calculation in order to achieve the prevalent air and heat distribution. It conducted to reduce the possibility buner in producing high value of ash content. In this study the activated carbon size is divided into 2 types which are powdered AC and granular AC. Powdered AC especially used in lab scale and it most recommended for batch treatment of liquid (water treatment plant). It caused by slower diffusion through particles and high pressure loss across the bed. Granular activated carbon is used in pilot plant and industrial sector and in this case, it applied to air filter because better mechanical by sacrificing some efficiency. Testing process include iodine number which typically in the range of $500-1200 \mathrm{mg} / \mathrm{g}$, water content is performed under temperature of $100^{\circ} \mathrm{C}$, ash content is performed using atmospheric furnace with various temperature of $650^{\circ} \mathrm{C}, 700^{\circ} \mathrm{C}$ and $850^{\circ} \mathrm{C}$ and bulk density analyzed through drying under temperature of $100^{\circ} \mathrm{C}$ for 1 hour and weighed. Adsorption analysis is conducted using dipping methods where the activated carbon is dehydrated in a convection oven at $150^{\circ} \mathrm{C}$. Indoor air quality improvement is conducted by $\mathrm{AC}$ filter (Figure 6) which performed by a pilot-scale acrylic chamber with a volume of $1 \mathrm{~m} 3$ and temperature as well as the humidity in the chamber were maintained at $20-26^{\circ} \mathrm{C}$ and $40-70$ $\%$, respectively.

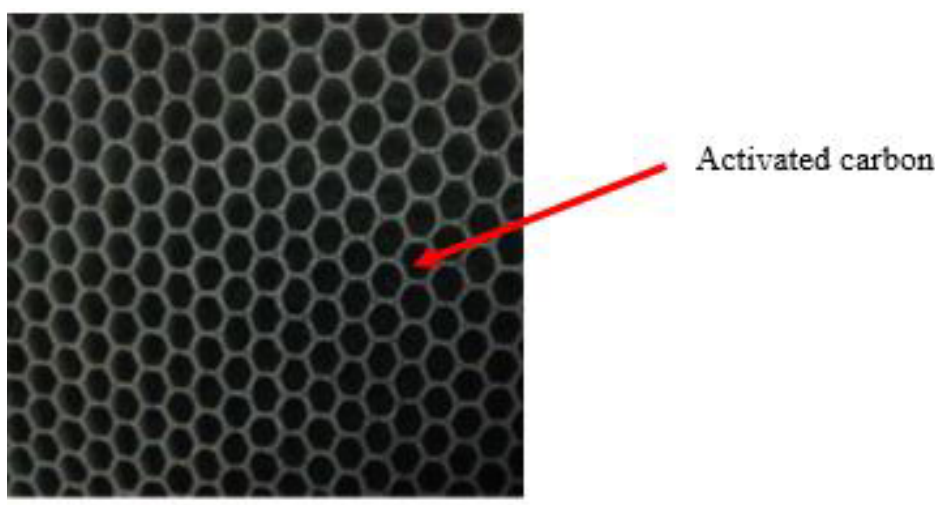

Fig. 6. Concept of AC filter [37].

\section{Conclusion}

AC filter has been developed by previous researcher but it still very challenging to explored. This research, proposed AC air filter completed by effective technique for improving indoor air quality. This paper proposes an innovative method inactivate an activated carbon by physical, chemical and combination of physical and chemical with new treatment parameter. Approach technology for burning process is one of the innovative technique in achieving high quality of activated carbon.

The authors would like to thank the Ministry of Higher Education Malaysia for FRGS fund vot 1216, ORICC, Universiti Tun Hussein Onn Malaysia (UTHM) and Centre for Graduate Studies - UTHM. 


\section{References}

1. M. Frontezak, P. Wargocki, Build. Environ., 46, 922 (2011)

2. C.K.H. Yu, M. Li, V. Chan, A.C.K. Lai, Build. Environ., 76, 73 (2014)

3. B.F. Yua, Z.B. Hua, M. Liua, H.L. Yang, Q.X. Kong and Y.H. Liu, Int. J. Refrig., 32, 3 (2009)

4. D. Das, V. Gaur, N. Verma, Carbon, 42, 2949 (2004)

5. W.K. Jo, H.H. Chun, Aerosol. Air Qual. Res., 14, 347 (2014)

6. Z. Eugenija, E.S. Neil, M. Jadranka, P.C. Jasna, D.J. Jagoda, M.P. Branka, Biol., 111, 37 (2009)

7. B. Guieysse, C. Hort, V. Platel, R. Munoz, M. Ondarts, S. Revah, Biotechnol. Adv., 26, 398 (2008)

8. J.Y. Yoo, C.J. Park, K.Y. Kim, Y. Son, C. Kang, J.M. Wolfson, I. Jung, S. Lee, P. Koutrakis, J. Hazard. Mater., 289, 184 (2015)

9. E. Kabir, K.H. Kim, Asian J. Atmos. Environ., 6, 137 (2012)

10. F. Haghighat, C.S. Lee, B. Pant, G. Bolourani, N. Lakdawala, A. Bastani, Atmos Environ., 42, 8176 (2008)

11. F.I. Khan, A.K. Ghoshal, J. Loss Prev. Process Ind., 13, 527 (2000)

12. C.H. Reed, S.J. Nabinger, S.J. Emmerich, Build. Environ., 43, 368 (2008)

13. Gallego, E. Roca, F.J. Perales and J.F. Guardino, Build. Environ., 67,14 (2014)

14. I. Adedayo, A.O. Inegbenebor, H.I. Boyo, ARPN Journal of Science and Technology, 2, 2225 (2012)

15. Y.B. Onundi, A.A. Mamun, M.F. Al Khatib and Y.M. Ahmed, Int. J. Environ. Sci. Tech., 7, 751 (2010)

16. W.B. Wan Nik, M.M. Rahman, A.M. Yusof, F.N. Ani, C.M. Che Adnan, Proceedings of the 1st International Conference on Natural Resources Engineering \& Technology, Putrajaya, Malaysia, 646 (2006)

17. N.H. Hasan, M.R. Said, A.M. Leman, International Journal of Environmental Engineering Science and Technology Research, 1, 28 (2013)

18. S.E. Abechi, C.E. Gimba, A. Uzairu and Y.A. Dallatu, Research Journal of Chemical Sciences, 3, 54 (2013)

19. T.A. Metts, S.A. Batterman, Chemosphere, 62, 34 (2006)

20. S. Wu, B. Dong, T. Qiao, J. Zhang, Zhejiang Univ Sci., A, 9, 1576 (2008)

21. A.A. Ismaiel, M.K. Aroua, R. Yusoff, Chem. Eng. J., 225, 306 (2013)

22. M. A. Sidheswaran, H. Destaillats, D.P. Sullivan, S. Cohn, and W.J. Fisk, Build. Environ., 47, 357 (2012)

23. R. Abdullah, M.B. Wahid. World palm oil supply, demand, price and prospect: Focus on Malaysian and Indonesian palm oil industry, (Malaysian Palm Oil Board (MPOB), 2010).

24. A.A. Niya,W.M. Ashri, W. Daud and S. Farouq, Eng. Res. Des., 8, 657 (2011)

25. J. Guo, W.S. Xu, Y.L. Chen, A.C. Lua, J. Colloid Interface Sci., 281, 285 (2005)

26. A.B.M. Noor, M.A.B.M. Nawi, J. Phys. Sci., 19, 93 (2008)

27. D. Adinata, W.M.A.W. Daud, M.A. Kheireddine, Bioresour. Technol., 98, 145 (2007)

28. I.A.W. Tan, A.L. Ahmad, B.H. Hameed, Bioresour. Technol., 100, 1494 (2009)

29. W.M.A.W. Daud, W.S.W. Ali, Bioresour. Technol., 93, 63 (2004)

30. I.A.W. Tan, A.I. Ahmad, B.H. Hameed, Colloids Surf., A 318, 88 (2008)

31. A. Arami-Niya, W.M.A.W. Daud, S.M. Farouq, J. Anal. Appl. Pyrolysis., 89, 197 (2010)

32. A. Afrane, Microporous Mesoporous Mater., 112, 284 (2008) 
33. W.K. Koo, N.A. Gani, M.S. Shamsuddin, N.S. Subki, M.A. Sulaiman, J. Trop. Resour. Sustain., Sci. 3, 54 (2015)

34. T.S. Anirudhan and S.S. Sreekumari, J. Environ. Sci., 23, 1989 (2011)

35. S. Sethupathi, M.J.K. Bashir, Z.A. Akbar, A.R. Mohamed, Waste Manage. Res., 33, $303(2015)$

36. E.C. Okoroigwe, C.M. Saffron, P.D. Kamdem, J. Chem. Eng. Mater. Sci., 5, 1 (2014)

37. Suki, Honeycomb activated carbon air filter, (Dongguan ICM Environment Tech Co., Ltd., 2015)

38. DOSH. Industry Code of Practice on Indoor Air Quality-Department of Occupational Safety and Health Ministry of Human Recourses Malaysia, (JKKP $\mathrm{DP}(\mathrm{S}), 2010)$ 